\title{
Radon concentration anomaly characteristics in the North-South seismic belt before strong earthquake
}

\author{
Xiaoyun $\mathrm{Su}^{1,2^{*}}$, Xiaopeng Yang ${ }^{1,2}$, Ting Song ${ }^{1,2}$, Wencai Wang ${ }^{1,2}$, Lijun Chen ${ }^{1,2}$ \\ ${ }^{1}$ Gansu Earthquake Agency, Lanzhou, Gansu 730000, China; \\ ${ }^{2}$ Lanzhou National Geophysical Observation and Research Station, Lanzhou, Gansu 730000, China;
}

\begin{abstract}
Seismic underground fluids play an important role in earthquake prediction studies and tracking. Nearly 30 years of radon concentration monitoring data at 42 observation sites in the North-South seismic belt $\left(22^{\circ}-35^{\circ} \mathrm{N}, 100^{\circ}-110^{\circ} \mathrm{E}\right)$ were collected from the National Earthquake Data Center of China Earthquake Networks Center. The possible precursor anomalies of observed radon concentration in the belt before several strong earthquakes were investigated and their spatial distribution, evolution, and variation characteristics were analyzed. The results showed that radon concentration precursor anomalies before several strong earthquakes were high, and the morphological characteristics are relatively complex. The anomaly mainly shows the turning point or accelerating change of trend background change; longer anomaly durations tend to be concentrated around epicenters. The number of observation points with anomalies was positively correlated with the proximity to the epicenter; the measurement points closest to the epicenter exhibited earlier trend anomalies. The research has important practical significance and scientific value for understanding the relationship between radon concentration anomaly and strong earthquake.
\end{abstract}

\section{Introduction}

The North-South seismic belt is one of the most intensely seismic regions in mainland China, with 71 recorded earthquakes of magnitude 7 or higher [1]. After the Wenchuan earthquake on May 12, 2008, the North-South seismic belt has entered a new active period of strong earthquakes [2]. According to the earthquake catalog of the China Earthquake Networks Center, twenty-six strong earthquakes of magnitude 6 or higher have occurred in the North-South seismic belt since 2008, including five earthquakes of magnitude 7 or higher, exhibiting characteristics of North-South round-trip migration. After the earthquake, there have been many studies on the possible anomalies of water radon before the earthquake [3-5]. However, water radon, as a means of seismic underground fluid observation, is primarily studied by taking a medium-strong earthquake as an example [6-8] and selecting certain "sensitive" measurement points [911] as targets of anomaly information in the local area [1213]. However, the overall variation characteristics of preseismic radon concentration anomalies and their formation mechanism remain understudied.

Radon is a suitable geochemical component for evaluating tectonic fracture distribution and fault activity and seismic activity [14]. Radon is produced following the decay of radium, thorium, and other radioactive elements. Its chemical properties are stable, and it can migrate not only in the gaseous state in the geological environment but also with the groundwater in the dissolved state and migrate from the deep underground to the surface, it is an indicator of deep earth information and can bring information reflecting the state of underground geology $[15,16]$. Radon, as a medium and long-term indicator of geochemical precursors, plays an important role in revealing the relationship between abnormal changes of underground fluids and the preparation and occurrence of earthquake. In the nearly 10 years of past research, most scholars have carried out research work for radon observation at a single station with single measurement. However, For the strong earthquake with great destruction, the study of single station and local area still has some limitations. Carrying out large-scale research is greatly valuable for revealing the overall characteristics and formation mechanism of earthquake precursors.

In this paper, we analyzed the overall variation characteristics of radon concentration anomalies before several strong earthquakes which occurred in NorthSouth earthquake belt in the past 10 years: the magnitude 8.0 Wenchuan earthquake on May 12, 2008, the magnitude 7.0 Lushan earthquake on April 20, 2013, the magnitude 6.6 Minxian-Zhangxian earthquake on July 22, 2013 and the magnitude 7.0 Jiuzhaigou earthquake on August 8, 2017. It is expected to provide further data support for improving the level of understanding of earthquake precursors and earthquake monitoring and prediction.

\section{Data collection}

In this paper 42 radon concentration measurements of the China Earthquake Networks Center in the study area range

*Corresponding author e-mail: suxy@gsdzj.gov.cn 
$\left(22^{\circ}-35^{\circ} \mathrm{N}, 100^{\circ}-110^{\circ}\right.$ E) were collected and radon concentration anomalies before four strong earthquakes were sorted out to analyze their general characteristics. Figure 1 shows the distribution of radon concentration observations in the North-South seismic belt.



Figure 1. Distribution of radon concentration measurement points in the North-South seismic belt

\section{Analysis of monitoring results}

\subsection{Radon concentration anomalies and earthquake precursors}

This paper collected and collated 45 radon concentration measurements before the earthquake from 42 stations within the North-South seismic belt (Figure 1) for nearly 30 years; 23 anomalies before the Wenchuan earthquake (Table 1), 23 anomalies before the Lushan earthquake (Table 2), 14 anomalies before the Minxian earthquake (Table 3), and 26 anomalies before the Jiuzhaigou earthquake were collated (Table 4), and the maximum range from anomalies to the epicenter was between 675 and $1028 \mathrm{~km}$.

Table 1. Information on radon concentration anomalies before the 8.0 Wenchuan earthquake

\begin{tabular}{|c|c|c|c|c|c|}
\hline NO. & Station & $\begin{array}{c}\text { Observ } \\
\text { ation } \\
\text { items }\end{array}$ & $\begin{array}{c}\text { Epicenter } \\
\text { distance } \\
/ \mathrm{km}\end{array}$ & $\begin{array}{c}\text { Anomal } \\
\text { y start } \\
\text { time }\end{array}$ & $\begin{array}{c}\text { Anomaly } \\
\text { features }\end{array}$ \\
\hline 1 & Tangyu & $\begin{array}{c}\text { Water } \\
\text { radon }\end{array}$ & 546.81 & $03 / 2006$ & $\begin{array}{c}\text { Reversal } \\
\text { and rise }\end{array}$ \\
\hline 2 & Gaojiacun & $\begin{array}{c}\text { Water } \\
\text { radon }\end{array}$ & 507.33 & $03 / 2005$ & Trend rise \\
\hline 3 & Hanzhong & $\begin{array}{c}\text { Water } \\
\text { radon }\end{array}$ & 412.98 & $04 / 2005$ & Trend rise \\
\hline 4 & $\begin{array}{c}\text { Zhouzhi } \\
\text { Xiguan }\end{array}$ & $\begin{array}{c}\text { Gas } \\
\text { radon }\end{array}$ & 572.15 & $05 / 2008$ & $\begin{array}{c}\text { Sudden } \\
\text { drop }\end{array}$ \\
\hline 5 & $\begin{array}{c}\text { Tonghai } \\
\text { Gaoda }\end{array}$ & $\begin{array}{c}\text { Gas } \\
\text { radon }\end{array}$ & 781.07 & $05 / 2007$ & $\begin{array}{c}\text { Sudden } \\
\text { rise }\end{array}$ \\
\hline 6 & $\begin{array}{c}\text { Mile Shiju } \\
\text { Gas } \\
\text { radon }\end{array}$ & 751.68 & $05 / 2008$ & $\begin{array}{c}\text { Sudden } \\
\text { rise, } \\
\text { reversal } \\
\text { and drop }\end{array}$ \\
\hline 7 & $\begin{array}{c}\text { Panzhihua } \\
\text { Well No. } \\
05\end{array}$ & $\begin{array}{c}\text { Water } \\
\text { radon }\end{array}$ & 527.69 & $03 / 2007$ & $\begin{array}{c}\text { Trend } \\
\text { reversal }\end{array}$ \\
\hline 8 & $\begin{array}{c}\text { Panzhihua } \\
\text { Turtle } \\
\text { Well }\end{array}$ & $\begin{array}{c}\text { Water } \\
\text { radon }\end{array}$ & 519.1 & $11 / 2007$ & $\begin{array}{c}\text { Sudden } \\
\text { rise, trend } \\
\text { reversal } \\
\text { and drop }\end{array}$ \\
\hline
\end{tabular}

\begin{tabular}{|c|c|c|c|c|c|}
\hline 9 & Lixian & $\begin{array}{l}\text { Water } \\
\text { radon }\end{array}$ & 79.35 & $11 / 2007$ & $\begin{array}{l}\text { Reversal } \\
\text { and rise }\end{array}$ \\
\hline 10 & Yanyuan & $\begin{array}{l}\text { Water } \\
\text { radon }\end{array}$ & 437.94 & $02 / 2000$ & $\begin{array}{l}\text { Trend } \\
\text { reversal }\end{array}$ \\
\hline 11 & Zhaojue & $\begin{array}{l}\text { Water } \\
\text { radon }\end{array}$ & 338.43 & $04 / 2004$ & $\begin{array}{l}\text { Trend } \\
\text { reversal }\end{array}$ \\
\hline 12 & Ya'an & $\begin{array}{l}\text { Water } \\
\text { radon }\end{array}$ & 98.85 & $09 / 2005$ & $\begin{array}{c}\text { Trend } \\
\text { reversal } \\
\text { and drop }\end{array}$ \\
\hline 13 & Ganzi (y) & $\begin{array}{l}\text { Water } \\
\text { radon }\end{array}$ & 329.12 & $12 / 2006$ & $\begin{array}{c}\text { Trend } \\
\text { reversal } \\
\text { and drop }\end{array}$ \\
\hline 14 & $\begin{array}{l}\text { Xichang } \\
\text { Taihe }\end{array}$ & $\begin{array}{l}\text { Water } \\
\text { radon }\end{array}$ & 370.86 & $05 / 2006$ & $\begin{array}{c}\text { Trend } \\
\text { reversal }\end{array}$ \\
\hline 15 & Xichang & $\begin{array}{l}\text { Water } \\
\text { radon }\end{array}$ & 366.81 & $04 / 2006$ & $\begin{array}{l}\text { Trend } \\
\text { reversal }\end{array}$ \\
\hline 16 & Songpan & $\begin{array}{l}\text { Water } \\
\text { radon }\end{array}$ & 184.36 & $01 / 2003$ & $\begin{array}{l}\text { Drop } \\
\text { trend }\end{array}$ \\
\hline 17 & $\begin{array}{c}\text { Wudu } \\
\text { Diangou }\end{array}$ & $\begin{array}{l}\text { Water } \\
\text { radon }\end{array}$ & 304.36 & $01 / 2006$ & $\begin{array}{l}\text { Reversal } \\
\text { and drop }\end{array}$ \\
\hline 18 & $\begin{array}{c}\text { Wushan } \\
\text { Spring } \\
\text { No. } 1\end{array}$ & $\begin{array}{l}\text { Water } \\
\text { radon }\end{array}$ & 434.76 & $01 / 2003$ & $\begin{array}{l}\text { Drop } \\
\text { trend in } \\
2003, \\
\text { reversal } \\
\text { and rise } \\
\text { in } 2007 \\
\end{array}$ \\
\hline 19 & $\begin{array}{l}\text { Wushan } \\
\text { Spring } \\
\text { No. } 22\end{array}$ & $\begin{array}{l}\text { Water } \\
\text { radon }\end{array}$ & 407.24 & $01 / 2003$ & $\begin{array}{l}\text { Drop } \\
\text { trend in } \\
2003, \\
\text { reversal } \\
\text { and rise } \\
\text { in } 2007\end{array}$ \\
\hline 20 & $\begin{array}{c}\text { Qingshui } \\
\text { Hot } \\
\text { Spring }\end{array}$ & $\begin{array}{l}\text { Water } \\
\text { radon }\end{array}$ & 493.6 & $01 / 2006$ & $\begin{array}{c}\text { Drop } \\
\text { trend in } \\
2003, \\
\text { reversal } \\
\text { and rise } \\
\text { in } 2007 \\
\end{array}$ \\
\hline 21 & $\begin{array}{c}\text { Pingliang } \\
\text { Fujiancha } \\
\text { ng }\end{array}$ & $\begin{array}{l}\text { Water } \\
\text { radon }\end{array}$ & 588.74 & $01 / 2007$ & $\begin{array}{l}\text { Reversal } \\
\text { and rise }\end{array}$ \\
\hline 22 & $\begin{array}{l}\text { Tianshui } \\
\text { Wulipu }\end{array}$ & $\begin{array}{l}\text { Water } \\
\text { radon }\end{array}$ & 456.38 & $01 / 2001$ & $\begin{array}{c}\text { Reversal } \\
\text { and rise }\end{array}$ \\
\hline 23 & $\begin{array}{c}\text { Tongwei } \\
\text { Hot } \\
\text { Spring } \\
\end{array}$ & $\begin{array}{l}\text { Water } \\
\text { radon }\end{array}$ & 498.41 & 09/2007 & $\begin{array}{c}\text { Trend } \\
\text { drop - rise }\end{array}$ \\
\hline
\end{tabular}

Table 2. Information on radon concentration anomalies before the Lushan earthquake

\begin{tabular}{|c|c|c|c|c|c|}
\hline $\begin{array}{l}\mathrm{N} \\
\mathrm{O}\end{array}$ & Station & $\begin{array}{l}\text { Observati } \\
\text { on items }\end{array}$ & $\begin{array}{l}\text { Epicent } \\
\text { er } \\
\text { distanc } \\
\text { e/km }\end{array}$ & $\begin{array}{l}\text { Anomal } \\
\text { y start } \\
\text { time }\end{array}$ & $\begin{array}{l}\text { Anomaly } \\
\text { features }\end{array}$ \\
\hline 1 & Tangyu & $\begin{array}{l}\text { Water } \\
\text { radon }\end{array}$ & 627.57 & $07 / 2012$ & $\begin{array}{l}\text { Sudden rise, } \\
\text { reversal and } \\
\text { drop }\end{array}$ \\
\hline 2 & Gaojiacun & $\begin{array}{l}\text { Water } \\
\text { radon }\end{array}$ & 591.41 & $09 / 2011$ & $\begin{array}{c}\text { Trend } \\
\text { reversal }\end{array}$ \\
\hline 3 & Lintong & $\begin{array}{l}\text { Water } \\
\text { radon }\end{array}$ & 659.67 & $10 / 2012$ & $\begin{array}{l}\text { Reversal } \\
\text { and drop }\end{array}$ \\
\hline 4 & Hanzhong & $\begin{array}{l}\text { Water } \\
\text { radon }\end{array}$ & 490.7 & $02 / 2013$ & $\begin{array}{l}\text { V-shaped } \\
\text { changes }\end{array}$ \\
\hline 5 & $\begin{array}{c}\text { Hanzhong } \\
\text { Yangxian }\end{array}$ & Gas radon & 532.41 & $07 / 2011$ & $\begin{array}{c}\text { Trend } \\
\text { acceleration }\end{array}$ \\
\hline 6 & $\begin{array}{l}\text { Mile } \\
\text { Shiju }\end{array}$ & Gas radon & 675 & $11 / 2012$ & $\begin{array}{c}\text { Trend } \\
\text { reversal }\end{array}$ \\
\hline 7 & $\begin{array}{c}\text { Panzhihua } \\
\text { Well No. } \\
05\end{array}$ & $\begin{array}{l}\text { Water } \\
\text { radon }\end{array}$ & 442 & $03 / 2012$ & $\begin{array}{l}\text { Trend rise - } \\
\text { drop }\end{array}$ \\
\hline 8 & $\begin{array}{c}\text { Panzhihua } \\
\text { Turtle } \\
\text { Well } \\
\end{array}$ & $\begin{array}{l}\text { Water } \\
\text { radon }\end{array}$ & 432.97 & $02 / 2012$ & Sudden rise \\
\hline 9 & Yanyuan & $\begin{array}{l}\text { Water } \\
\text { radon }\end{array}$ & 351.22 & $10 / 2012$ & $\begin{array}{l}\text { Increased } \\
\text { volatility }\end{array}$ \\
\hline 10 & Zhaojue & $\begin{array}{l}\text { Water } \\
\text { radon }\end{array}$ & 256.75 & $05 / 2012$ & $\begin{array}{c}\text { Trend } \\
\text { acceleration }\end{array}$ \\
\hline 11 & Ya'an & $\begin{array}{l}\text { Water } \\
\text { radon }\end{array}$ & 14.74 & $04 / 2012$ & Sudden rise \\
\hline
\end{tabular}




\begin{tabular}{|c|c|c|c|c|c|}
\hline 12 & Ganzi (y) & $\begin{array}{c}\text { Water } \\
\text { radon }\end{array}$ & 320.15 & $12 / 2012$ & Sudden rise \\
\hline 13 & Xichang & $\begin{array}{c}\text { Water } \\
\text { radon }\end{array}$ & 281.34 & $03 / 2013$ & $\begin{array}{c}\text { Trend } \\
\text { reversal }\end{array}$ \\
\hline 14 & Songpan & $\begin{array}{c}\text { Water } \\
\text { radon }\end{array}$ & 267.38 & $03 / 2013$ & Sudden drop \\
\hline 15 & Bayisi & $\begin{array}{c}\text { Water } \\
\text { radon }\end{array}$ & 114.83 & $01 / 2012$ & $\begin{array}{c}\text { Trend } \\
\text { reversal }\end{array}$ \\
\hline 16 & $\begin{array}{c}\text { Xichangc } \\
\text { huan Well } \\
\text { No. 32 }\end{array}$ & Gas radon & 281.34 & $08 / 2012$ & Sudden rise \\
\hline 17 & $\begin{array}{c}\text { Xichangc } \\
\text { huan Well } \\
\text { No. 32 }\end{array}$ & $\begin{array}{c}\text { Water } \\
\text { radon }\end{array}$ & 281.34 & $08 / 2012$ & Sudden rise \\
\hline 18 & $\begin{array}{c}\text { Wudu } \\
\text { Diangou }\end{array}$ & $\begin{array}{c}\text { Water } \\
\text { radon }\end{array}$ & 391.07 & $09 / 2011$ & $\begin{array}{c}\text { Trend } \\
\text { acceleration }\end{array}$ \\
\hline 19 & $\begin{array}{c}\text { Wushan } \\
\text { Spring } \\
\text { No. 2 }\end{array}$ & $\begin{array}{c}\text { Water } \\
\text { radon }\end{array}$ & 521.1 & $05 / 2012$ & $\begin{array}{c}\text { Sudden rise, } \\
\text { trend } \\
\text { reversal }\end{array}$ \\
\hline 20 & $\begin{array}{c}\text { Wushan } \\
\text { Spring } \\
\text { No. 22 }\end{array}$ & $\begin{array}{c}\text { Water } \\
\text { radon }\end{array}$ & 493.73 & $03 / 2012$ & $\begin{array}{c}\text { Reversal } \\
\text { and rise }\end{array}$ \\
\hline 21 & $\begin{array}{c}\text { Pingliang } \\
\text { Fujiancha } \\
\text { ng }\end{array}$ & $\begin{array}{c}\text { Water } \\
\text { radon }\end{array}$ & 675.28 & $11 / 2011$ & $\begin{array}{c}\text { Reversal } \\
\text { and drop }\end{array}$ \\
\hline 22 & $\begin{array}{c}\text { Tianshui } \\
\text { Wulipu }\end{array}$ & $\begin{array}{c}\text { Water } \\
\text { radon }\end{array}$ & 542.98 & $05 / 2012$ & $\begin{array}{c}\text { Reversal } \\
\text { and drop }\end{array}$ \\
\hline 23 & $\begin{array}{c}\text { Tongwei } \\
\text { Hot } \\
\text { Spring }\end{array}$ & $\begin{array}{c}\text { Water } \\
\text { radon }\end{array}$ & 584.7 & $10 / 2011$ & $\begin{array}{c}\text { Trend } \\
\text { reversal }\end{array}$ \\
\hline
\end{tabular}

Table 3. Information on anomalous radon concentrations before the Minxian earthquake

\begin{tabular}{|c|c|c|c|c|c|}
\hline NO & Station & $\begin{array}{c}\text { Observati } \\
\text { on items }\end{array}$ & $\begin{array}{c}\text { Epicenter } \\
\text { distance/k } \\
\mathrm{m}\end{array}$ & $\begin{array}{c}\text { Anomal } \\
\text { y start } \\
\text { time }\end{array}$ & $\begin{array}{c}\text { Anomaly } \\
\text { features }\end{array}$ \\
\hline 1 & Tangyu & $\begin{array}{c}\text { Water } \\
\text { radon }\end{array}$ & 342.35 & $05 / 2013$ & $\begin{array}{c}\text { Big } \\
\text { sudden } \\
\text { jump, } \\
\text { reversal } \\
\text { and rise }\end{array}$ \\
\hline 2 & Gaojiacun & $\begin{array}{c}\text { Water } \\
\text { radon }\end{array}$ & 263.78 & $06 / 2013$ & $\begin{array}{c}\text { V-shaped } \\
\text { changes }\end{array}$ \\
\hline 3 & Lintong & $\begin{array}{c}\text { Water } \\
\text { radon }\end{array}$ & 359.92 & $04 / 2013$ & $\begin{array}{c}\text { Reversal } \\
\text { and drop }\end{array}$ \\
\hline 4 & $\begin{array}{c}\text { Zhouzhi } \\
\text { Xiguan }\end{array}$ & Gas radon & 370.18 & $06 / 2013$ & $\begin{array}{c}\text { Reversal } \\
\text { and } \\
\text { sudden } \\
\text { rise }\end{array}$ \\
\hline 5 & $\begin{array}{c}\text { Hanzhong } \\
\text { Yangxian }\end{array}$ & Gas radon & 329.25 & $06 / 2013$ & $\begin{array}{c}\text { Trend } \\
\text { accelerati } \\
\text { on }\end{array}$ \\
\hline 6 & Zhaojue & $\begin{array}{c}\text { Water } \\
\text { radon }\end{array}$ & 734.68 & $05 / 2013$ & $\begin{array}{c}\text { Reversal } \\
\text { and drop }\end{array}$ \\
\hline 7 & Ya'an & $\begin{array}{c}\text { Water } \\
\text { radon }\end{array}$ & 493.85 & $07 / 2012$ & $\begin{array}{c}\text { Sudden } \\
\text { rise }\end{array}$ \\
\hline 8 & Songpan & $\begin{array}{c}\text { Water } \\
\text { radon }\end{array}$ & 213.12 & $05 / 2013$ & $\begin{array}{c}\text { Continued } \\
\text { drop }\end{array}$ \\
\hline 9 & $\begin{array}{c}\text { Wudu } \\
\text { Diangou }\end{array}$ & $\begin{array}{c}\text { Water } \\
\text { radon }\end{array}$ & 137.06 & $01 / 2013$ & $\begin{array}{c}\text { Reversal } \\
\text { and rise }\end{array}$ \\
\hline 10 & $\begin{array}{c}\text { Wushan } \\
\text { Spring } \\
\text { No. 1 }\end{array}$ & $\begin{array}{c}\text { Water } \\
\text { radon }\end{array}$ & 79.73 & $03 / 2013$ & $\begin{array}{c}\text { Reversal } \\
\text { and rise }\end{array}$ \\
\hline 11 & $\begin{array}{c}\text { Wushan } \\
\text { Spring } \\
\text { No. 22 }\end{array}$ & $\begin{array}{c}\text { Water } \\
\text { radon }\end{array}$ & 76.98 & $04 / 2013$ & $\begin{array}{c}\text { Trend } \\
\text { accelerati } \\
\text { on }\end{array}$ \\
\hline 12 & $\begin{array}{c}\text { Pingliang } \\
\text { Fujiancha } \\
\text { ng }\end{array}$ & $\begin{array}{c}\text { Water } \\
\text { radon }\end{array}$ & 253.33 & $04 / 2013$ & $\begin{array}{c}\text { Reversal } \\
\text { and rise }\end{array}$ \\
\hline 13 & $\begin{array}{c}\text { Tianshui } \\
\text { Wulipu }\end{array}$ & $\begin{array}{c}\text { Water } \\
\text { radon }\end{array}$ & 152.97 & $03 / 2013$ & $\begin{array}{c}\text { Sudden } \\
\text { rise }\end{array}$ \\
\hline 14 & $\begin{array}{c}\text { Tongwei } \\
\text { Hot } \\
\text { Spring }\end{array}$ & $\begin{array}{c}\text { Water } \\
\text { radon }\end{array}$ & 124.87 & $10 / 2011$ & $\begin{array}{c}\text { Trend } \\
\text { reversal }\end{array}$ \\
\hline & & & & & \\
\hline
\end{tabular}


earthquake was first anomalous in 2001, and the gas radon in Zhouzhi Xiguan occurred for the last time 9 days before the earthquake; the gas radon in Hanzhong Yangxian before the Lushan earthquake was first anomalous in 2011, and the water radon in Songpan occurred for the last time 28 days before the earthquake; the water radon in Tongwei Hot Spring before the Minxian-Zhangxian earthquake was first anomalous in 2011, and the gas radon in Zhouzhi Xiguan occurred for the last time 1 month before the earthquake; Water radon in Huayin before the Jiuzhaigou earthquake was first anomalous in 2014, and water radon in Panzhihua Well No. 05 occurred for the last time 23 days before the earthquake.

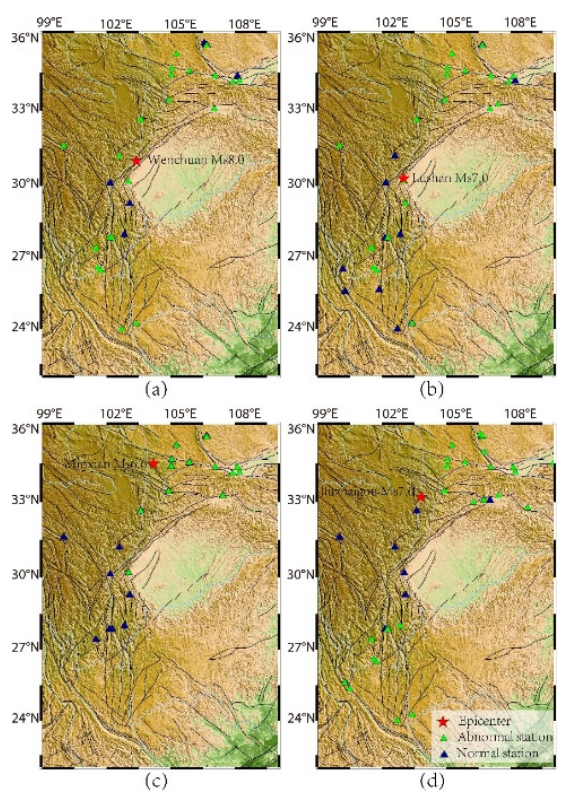

Figure 2. Spatial distribution of radon concentration anomalies in the North-South seismic belt before strong earthquakes

(a)Wenchuan Earthquake; (b)Lushan Earthquake; (c)Minxian Earthquake; (d)Jiuzhaigou Earthquake;

\subsection{Characteristics of typical anomalous changes}

The number of radon concentration precursor anomalies in the North-South seismic belt before several strong earthquakes is relatively high, and the morphological characteristics are relatively complex. Nonetheless, some regular change characteristics can be observed. The radon concentration anomalies are mainly manifested as reversal or accelerated changes of trend-based background changes. Figure 3 and Figure 4 show some typical curves of radon concentration anomalies. The black curve in the figure is the time series of original water radon observations, the blue straight line is the fitted trend of water radon observations, and the red vertical dashed line is the corresponding moment of earthquake onset. These anomalies show a general drooping or rising trend since the observation, and the trend showed reversal or accelerated changes some time before the earthquake. The water radon in Fujianchang began to rise 5 months before the Wenchuan earthquake. The water radon in Wulipu exhibited a clear dropping trend for many years and began to change approximately 2 years before the earthquake. The water radon in Ya'an exhibited a slower trend approximately 3 years before the earthquake. The water radon in Yangyuan exhibited a clear deviation from the trend approximately 3 years before the earthquake.

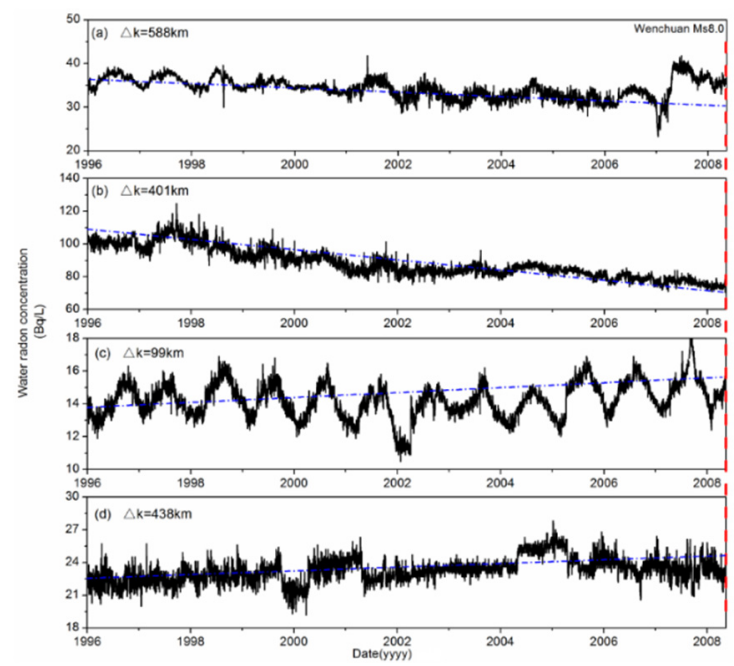

Figure 3. Typical water radon anomaly curves before the Wenchuan earthquake in different observation stations

(a) Fujianchang, (b) Wulipu, (c) Ya'an, (d) Yanyuan

The water radon in Panzhihua deviated significantly from the trend approximately 3 years before the Jiuzhaigou earthquake, that in Gaojiacun expressed a significant trend reversal approximately 4 years before the Wenchuan earthquake and showed a slower trend about 2 years before the Jiuzhaigou earthquake, and that in Yangyuan and Diangou deviated from the trend approximately 3 years before each earthquake.

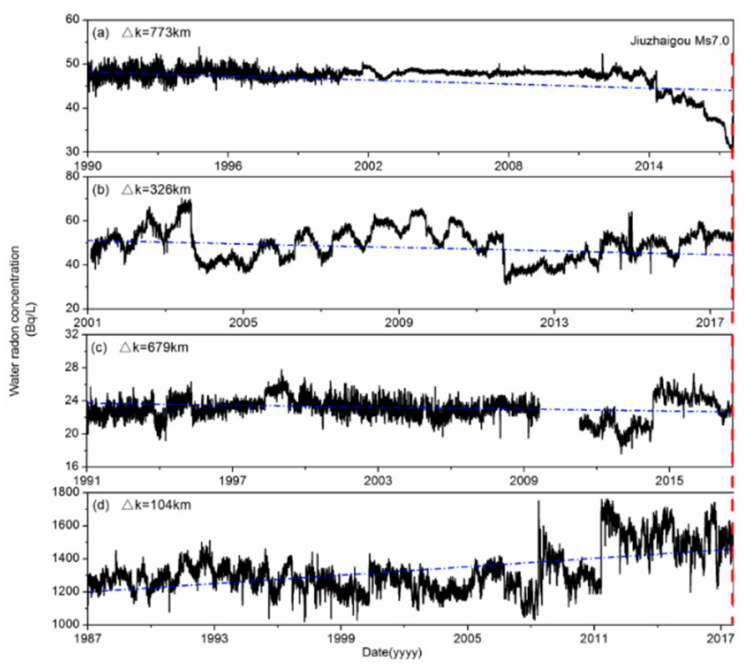

Figure 4. Typical water radon anomaly curves before the Jiuzhaigou earthquake in different observation stations

(a)Panzhihua, (b)Gaojiacun, (c) Yanyuan, (d)Diangou

\section{Conclusion}

In this paper the radon concentration anomalies of the 
North-South seismic belt $\left(22^{\circ}-35^{\circ} \mathrm{N}, 100^{\circ}-110^{\circ} \mathrm{E}\right)$ before the Wenchuan earthquake $(8.0 \mathrm{~N}$, May 12,2008$)$, the Lushan earthquake (7.0 N, April 20, 2013), the MinxianZhangxian earthquake(6.6 N, July 22, 2013), and the Jiuzhaigou earthquake (7.0 N, August 8, 2017) were collated. The variation characteristics, spatial distribution characteristics and spatiotemporal evolution characteristics of radon concentration anomalies were studied. The following conclusions were drawn:

(1) Among the 45 radon concentration measurement items nearly 30 years in the study area, The proportion of anomalies before the Wenchuan earthquake was $82 \%$; the proportion of anomalies before the Jiuzhaigou earthquake reached $72 \%$; the proportion of anomalies before the Lushan earthquake was $67 \%$; the proportion of anomalies before the Minxian earthquake was low; and the distance between radon concentration anomalies to the epicenter ranged from 14 to $1028 \mathrm{~km}$.

(2) The anomalies appeared several days to several years before the related earthquakes. In Wenchuan earthquake, the anomaly appeared in 2001 at the earliest and 9 days before the earthquake at the latest; The anomaly appeared in 2011 at the earliest and 28 days at the latest before the Lushan earthquake; Before the Minxian earthquake the anomalies appeared in 2011 at the earliest and 1 month at the latest; and the anomalies from 2014 at the earliest to 23 days at the latest before the Jiuzhaigou earthquake. The longer anomaly trends exhibit migration toward the epicenter: the closer to the epicenter area, the more observation points recorded anomalies. The measurement points closer to the epicenter showed anomalies earlier than surrounding points.

(3) The morphological characteristics of anomalies are quite complex and generally show the characteristics of trend-based anomalous changes. That is, for dropping or rising trends, they deviated from the multi-year linear trend to with accelerated changes within 1-3 years before the earthquake.

(4) The results of this study show that underground fluid precursor anomalies at large spatial and temporal scale may be observed before large earthquakes, which has important reference significance for improving our understanding of precursor observation data. Although this study is limited as a retrospective earthquake case study, it has important practical significance and scientific value for the in-depth understanding of the relationship between radon concentration anomalies and strong earthquakes and their formation mechanisms, requiring the accumulation of observation and seismic case data for further in-depth study.

\section{Acknowledgement}

This research was supported by the Lanzhou National Geophysical Observation and Research Station Fund (Grant No. 2020Y04), Science and Technology Research Plan of Gansu Province (Grant No. 20JR10RA503).

\section{References}

1. Shao ZG, Zhang LP. Study of strong earthquake recent trends on the northern segment of north-south seismic belt. Earthquake Research In China, 2013(1): 26-36.

2. Mei XP, Shao ZG, Zhang LP, et al. Study on potential earthquake risk of unbroken active faults in the northern segment of the North- South seismic zone. Acta Seismologica Sinica, 2012, 34(4): 509-525.

3. H Woith. Radon earthquake precursor: A short review. European PhysicalJournal SpecialTopics. 2015, 224(4): 611-627.

4. Qing Ye, Ramesh P. Singh, et al. Characteristic behavior of water radon associated with Wenchuan and Lushan earthquakes along Longmenshan fault. Radiation Measurements. 2015, 76: 44-53.

5. Gao L, Xing CQ. Two Abnormalities In Fluid Precursor Observation In Beijing Wuliying Well And Related Discussion. Seismology And Geology, 2011, 33(03): 644-652.

6. Yan R, Tian L, Wang GC, et al. Review and statistically characteristic analysis of underground fluid anomalies prior tothe 2008 Wenchuan M8.0 earthquake. Chinese Journalof Geophysics, 2018, 61(5): 1907-1921.

7. Wang XJ, Yang XY, NiuYP, et al. Analysis of Underground Fluid Anomalies Prior to the Wenchuan Ms8.0 Earthquake. China Earthquake Engineering Journal, 2014, 36(03): 688-696.

8. Deng ZH, Chen MH, Yang ZZ, et al. Water Vapor Anomalies Related To The Lushan And Wenchuan Earthquakes In The Longmenshan Mountains Area. Seismology And Geology, 2014, 36(03): 658-666.

9. Su HJ, Cao LL, ZHang H, et al. The Method for Identify the Earthquake Precursor of Water RadonTaking the Water Radon Anomaly of Qingshui Hot Spring in Gansu Province As an Example. Earthquake, 2020, 40(04): 198-213.

10. Li ZP, Zhao D, Yuan M. Abnormal changes of the gas radon data in Guza Seismic Station and the earthquake prediction. Earthquake Research In Sichuan, 2015(04): 24-28.

11. Liu DY. Discussion on Relation Between Water Temperature And Anomalies of And Radon In Ningbo Staion And Wenchuan Ms8.0 Earthquake. Journal of Geodesy And Geodynamics, 2008, 28(06): 53-55.

12. Su XY, Chen LJ, Wang WC, et al. Critical SlowingDown Phenomenon of Water Radon Concentrations in the Southeastern Gansu Region.China Earthquake Engineering Journal, 2020, 42(5): 1104-1110.

13. Yang XY, Wang Y, Wang JR, et al. The Relationship between Underground Fluid Anomalies in Southeastern Gansu and the Minxian Ms6.6 Earthquake. China Earthquake Engineering Journal, 2013, 35(04): 808-815.

14. ZHao ZS. The Geochemical Characteristics on Fault Gas of Main Active Faults in the Danger Earthquake Area of Gannan and Longnan. (Master Thesis) Lanzhou Institute of Seismology, CEA, Lanzhou, Gansu, China, 2012. 
15. Fleischer R L, Hart H R, Mogro-campero A. Radon emanation over an orebody: search for long distance transport of rad on.Instruments and Methods, 1980, 173: 169-181.

16. Wilkening $\mathrm{M} \mathrm{H}$, Watkins D E. Air exchange and Radon 222 cocentration in the Carlsbad cavens. Health Phys, 1976, 31(2): 139. 